such an excellent library as this. It embraces every class of literature, and appears especially rich in periodicals, and in works relating to Australasia.

THE last "Circular" of the Johns Hopkins University Library contains a list of the periodicals, including the scientific and literary publications of various societies, regularly received. Although newspapers and official reports are omitted, the list extends over eleven closely-printed columns, and probably contains the name of every periodical in the world in any way connected with science.

AN interesting bi-monthly periodical has just made its appearance in Colombo. It is entitled the Taprobanian; a Dravidian Journal of Oriental Studies in and around Ceylon in Natural History, Archaology, Philology, History, \&oc.," and is edited by Mr. Nevill, F.Z.S., of the Ceylon Civil Service. The first number contains various notes and queries, relating mainly to scientific subjects, and articles on Tamil inscriptions in Ceylon, comments on Ptolemy's geography, on Ceylonese inscriptions in the Asokha dialect, archæological reports on Ceylon (No. I), and on the Vaedda dialect. The whole of the contents of the thirty-two pages of the first issue is from the pen of the editor, who hopes to make his periodical a sto:ehouse of details, available hereafter for the elaboration of any special subject connected with the Tamil and other Dravidian races. $\mathrm{He}$ promises to do his utmost to procure for investigators in Europe, America, or elsewhere, any local information of scientific interest that they may seek. We hope the venture will have the success which the editor's learning and enterprise so well deserve.

WE are glad to notice the re-appearance of the Orientalist, another Ceylon periodical, containing articles of much scientific interest, and which has been noticed in NATURE. It ceased publication for some months, but the editor is now publishing double numbers to make up for lost time, which, it is only fair $t_{o}$ add, was due to negligence of suhscribers, not to that of its learned editor.

THE present numbe: (x. No. 23) of Excursions et Reconnaissances of French Cochin China contains the fourth part of M. Landes's article on Annamite tales and legends; but it is mainly occupied with the continuation of M. Tirant's long account of the fishes of Lower Cochin China and Cambodia.

THE inhabitants of Srinagar, Cashmere, have again been thrown into a state of alarm and consternation at the recurrence of earthquake shocks there. The first shock-a severe onewas felt on the night of the 15 th inst., and this has been followed by a constant series of slighter ones.

THE last number of La Nuova Scienzz contains instructive papers on "Modern Italian Thought," on " Cosmic Evolution," and on the "German Pessimist Philosophy." The first of these papers deals with Prof. G. Sergi's "Origin of Psychic Phenomena" (Milan, 1885), which forms the fortieth volume of the Italian "International Scientific Library," and which contains a useful summary of the arguments of physiologists and psychologists on the genesis and nature of psychic force. Sergi contends that psychis is merely a function, or rather an implement of the body, analagous to the teeth, claws, and other offensive and defensive members. Against this materialistic conception Prof. Caporali, author of the paper in question, and editor of La Nuova Scienza, contends that pscyhis is inherent in all forms of matter, from the atom to the highest organisms, and that it is the cause, not the effect, of motion, that is, of all progress and evolution. It is an error to suppose that the organ originates the psychic function, for the function precedes the organ. The lowest organisms, such as the amœbæ, have no differentiated organs, yet they exercise psychic functions, as shown by $\mathrm{O}$ Zacharia in his new work on "Organismen ohne Organe" (1885). Hence, to regard psychis as a mere function of the body, and introduce it later into the fully-developed nervous system as the product of the system, is neither pbilosophic nor scientific. The article on the German Pessimist school contains biographical notices and short summaries of the teachings of Schopenhauer, Von Hartmann, Geiger, Noiré, and other exponents of that philosophy. The Nuova Scienza, which continues to be conducted with remarkable learning and ability, deserves more general recognition than it appears to have yet received in this country.

TELEGRAPHS are extending with extraordinary rapidity over Southern China. At the present moment Pekin in the far north is connected by a direct line through Canton with Lungchow on the frontier of Tonquin, the extension from Canton to the latter place being made during the recent war, purely for military purposes. Thus we have one great line stretching through the Chinese Empire from north to south, and at the present moment an important line is being constructed along the southern borders of China through the provinces of Kwangtung, Kwangsi, and Yunnan. Starting from Nanking in Kwangsi, where it joins the Canton-Lungchow line, it will extend for nearly 600 miles to Mung-lih in South Yunnan, running for half the distance along the Yukiang, the name of the Canton river in its upper course. The work is being carried out by the Chinese themselves with the assistance of one European, and it is stated that during the recent war the Canton authorities equipped a complete field telegraph staff, the members of which were so thoroughly trained that they have been able to put up 35 miles of line in a single day for war purposes. Telegraphs have now secured a firm footing in China, and their extension over the whole country is a matter of time only, aided perhaps by political events. In the great movement towards a centralised Government now progressing in China the telegraph line will play a vital part, for it will utterly destroy the semi-independence of the provincial viceroys, hitherto secure in their remoteness from the seat of government.

THE additions to the Zoological Society's Gardens during the past week include a Green Monkey (Cercopithecus callitrichus $\$$ ) from West Africa, presented by Miss Hodgson; a Macaque Monkey (Macacus cynomolgus $\delta$ ) from India, presented by Mrs. Berens; an Arabian Gazelle (Gazella arabica + ) from Arabia, presented by Mr. John Patton; two Short-headed Phalangers (Belideus breviceps $\&$ \&) from Australia, presented by Mr. P. S. Abrahams, F.Z.S. ; a Ring-necked Parrakeet (Palcernis torquatus) from India, presented by Mrs. Morgan; two Indian Cobras (Naia tripudians) from India, presented by Mr. W. G. Burrows ; two European Tree Frogs (Hyla arborea), European, presented by Mrs. A. Bratton; two Catfish (Amiurus catus) from North America, presented by the National Fish Culture Association; two Mule Deer (Cariacus macrotis $+q$ ) from North America, a Triton Cockatoo (Cacatua triton) from New Guinea, deposited; two Barbary Wild Sheep (Ovis tragelaphus of ?) from North Africa, four Spotted-billed Ducks (Anas pacilorhyncha of $\delta q$ ) from India, purchased ; a Sambur Deer (Cervus aristotelis $\uparrow$ ), born in the Gardens.

\section{ASTRONOMICAL PHENOMENA FOR THE WEEK, 1885, NOVEMBER 22-28}

(FOR the reckoning of time the civil day, commencing at Greenwich mean midnight, counting the hours on to 24 , is here employed.)

\section{At Greenwich on November 22}

Sun rises, 7h. $33 \mathrm{~m}$. ; souths, $\mathrm{I}$ ih. $46 \mathrm{~m} .22^{\circ} 9 \mathrm{~s}$. ; sets, $16 \mathrm{~h}$. ons. ; decl. on meridian, $20^{\circ} \mathrm{I}^{\prime}$ S. : Sidereal Time at Sunset, 2oh. $7 \mathrm{~m}$. 
Moon (at Full) rises, 16h. 43m.; souths, oh. 25m.*; sets, 8h. $14 \mathrm{~m} .{ }^{*}$; decl. on meridian, $17^{\circ} \mathrm{r}^{\prime} \mathrm{N}$.

\begin{tabular}{|c|c|c|c|c|c|c|c|}
\hline Planet & & $\begin{array}{l}\text { Rises } \\
\text { h. m. }\end{array}$ & & $\begin{array}{l}\text { Souths } \\
\text { h. m. }\end{array}$ & & $\begin{array}{c}\text { Sets } \\
\text { h. m. }\end{array}$ & Decl. on meridian \\
\hline Mercury & & 932 & $\cdots$ & 139 & $\cdots$ & 1646 & $25^{\circ} 32 \mathrm{~S}$. \\
\hline Venus & $\ldots$ & II 28 & $\ldots$ & 158 & $\ldots$ & 1848 & $2513 \mathrm{~S}$. \\
\hline Mars & $\ldots$ & $233 \mathrm{I}^{*}$ & $\ldots$ & 631 & $\ldots$ & I3 3I & I0 $54 \mathrm{I}$ \\
\hline Jupiter & $\ldots$ & I 53 & $\ldots$ & 80 & $\ldots$ & 147 & $\circ 40 \mathrm{~N}$. \\
\hline Saturn & $\ldots$ & I8 $19^{*}$ & $\ldots$ & 227 & $\ldots$ & I0 35 & $\ldots \quad 2221 \mathrm{~N}$ \\
\hline
\end{tabular}

* Indicates that the rising is that of the preceding and the southing and setting those of the following day.

Occultations of Stars by the Moon

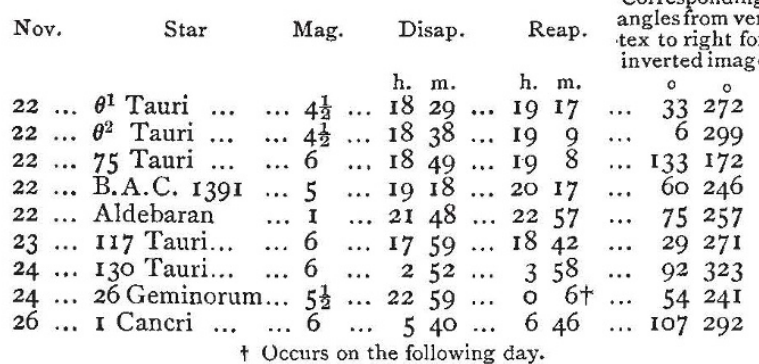

For further particulars in regard to the occultation of Aldebaran see NATURE, vol. xxxii, p. 610.

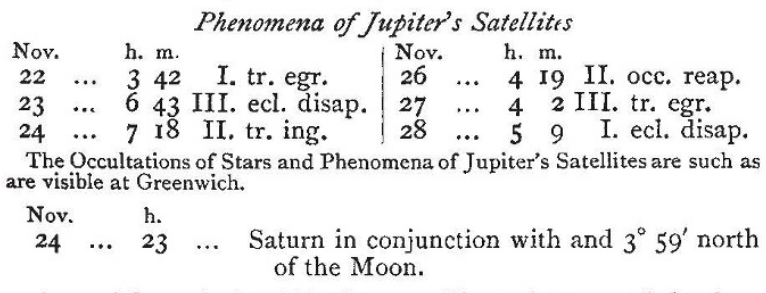

A special watch should be kept on November 27 and the days immediately preceding and following, in order to note whether there is any recurrence of the meteoric shower observed on November 27, 1872, and believed to be connected with Biela's comet. The radiant point is near $\gamma$ Andromedæ.

\section{CHEMICAL NOTES}

IN order to obtain constant temperatures easily maintained and completely under control, Messrs. Ramsay and Young (C. S. Fourmal, Trans., 1885, 640) employ vapours of the following compounds, and alter the pressure to which each vapour is subjected : carbon disulphide, ethyl alcohol, chlorobenzene, bromobenzene, aniline, methyl salicylate, bromonaphthalene, and mercury. By the use of the vapours of these bodies at various pressures, any desired temperature between that of the atmosphere and $360^{\circ}$ can be easily obtained. The authors have very carefully determined the vapour-pressures of these compounds for a large range of temperature. The methods of experiment are fully described, and the results are presented in the form of tables, which must prove of much service to those chemists and physicists who have occasion to raise pieces of apparatus to a known temperature, to vary that temperature if required, or to keep it perfectly constant for an indefinit a period.

As was noticed in these columns some time ago, Dixon has recently proved that a mixture of perfectly dry carbon monoxide and oxygen is not exploded by the passage of electric sparks; but that the presence of a minute quantity of water suffices to determine the combination of the gases. Dixon supposed that the action of the water was as represented in the following two equations :-

$$
\begin{aligned}
& \text { (I) } \mathrm{CO}+\mathrm{H}_{2} \mathrm{O}=\mathrm{CO}_{2}+\mathrm{H}_{2} \text {, } \\
& \text { (2) } 2 \mathrm{H}_{2}+\mathrm{O}_{2}=2 \mathrm{H}_{2} \mathrm{O} \text {. }
\end{aligned}
$$

Now Traube (Ber. IS, I890) has shown that carbon monoxide does not decompose water in complete absence of air or oxygen, even at very high temperatures; he has also shown that when moist carbon monoxide and oxygen are exploded together, hydrogen peroxide is an invariable product. Traube suggests that the following three changes probably occur during the explosion in question :-

(1) $\mathrm{CO}+2 \mathrm{H}_{2} \mathrm{O}+\mathrm{O}_{2}=\mathrm{CO}(\mathrm{OH})_{2}+\mathrm{H}_{2} \mathrm{O}_{2}$.

(2) $\mathrm{CO}+\mathrm{H}_{2} \mathrm{O}_{2}=\mathrm{CO}(\mathrm{OH})_{2}$.

(3) $2 \mathrm{CO}(\mathrm{OH})_{2}=2 \mathrm{CO}_{2}+2 \mathrm{H}_{2} \mathrm{O}$.

When hydrogen is burnt in moist oxygen, hydrogen peroxide is always produced, according to Traube. Whether a perfectly dry mixture of hydrogen and oxygen could or could not be exploded by electric sparks cannot be regarded as settled; Traube thinks that such a mixture would prove to be non-explosible. $\mathrm{He}$ regards the mutual action of hydrogen, oxygen and water as in all respects comparable with that of carbon monoxide, oxygen, and water, or with that of zinc, lead, and some other metals, oxygen, and water. The changes which occur in the explosion of moist hydrogen and oxygen are formulated by Traube thus :-

(I) $\mathrm{H}_{2}+2 \mathrm{H}_{2} \mathrm{O}+\mathrm{O}_{2}=2 \mathrm{H}_{2} \mathrm{O}+\mathrm{H}_{2} \mathrm{O}_{2}$.

(2) $\mathrm{H}_{2} \mathrm{O}_{2}+\mathrm{H}_{2}=2 \mathrm{H}_{2} \mathrm{O}$.

The occurrence of the second part of this reaction has been experimentally demonstrated by Traube.

IN continuing his experiments on nitrification, Warington (C.S. Fournal, Trans. 1885, 758) has shown that the limit of concentration (about 12 per cent.) beyond which urine ceases to be nitrifiable under ordinary conditions may be largely extended by adding gypsum to the liquid. A solution containing 50 per cent. of urine, and 22 milligrams of gypsum for every c.c. of urine, began to nitrify after about five months; solutions containing 15,20 , and 30 per cent. of urine began to nitrify after the lapse of 53, 68, and 78 days respectively. The gypsum prevents the accumulation of ammonium carbonate in the liquid.

J. H. VAN'T HOFF describes (Berichte, xviii. 2088) experiments on phenomena, analogous to those exhibited by gases at their "critical points," occurring during chemical decomposition. Phosphonium chloride, $\mathrm{PH}_{4} \mathrm{Cl}$, which melts at $25^{\circ}$, was heated to $50^{\circ}-5 \mathrm{I}^{\circ}$ at a pressure of $80-90$ atmospheres in a Cailletet's apparatus; under these conditions the line of separation between liquid and vapour disappeared, and, on cooling, the formation of nebulous streaks became plainly visible. It is well known that the vapour obtained by heating $\mathrm{PH}_{4} \mathrm{Cl}$ under ordinary conditions consists of $\mathrm{PH}_{3}+\mathrm{HCl}$; it is not possible to say to what extent the melted substance in van't Hoff's experiment consisted of a compound of $\mathrm{PH}_{3}$ and $\mathrm{HCl}$, and the gaseous part consisted of a mixture of these constituents, yet it seems certain that, when $\mathrm{PH}_{4} \mathrm{Cl}$, a compound which is chemically decomposed when vaporised, is heated to $50^{\circ}$ under a pressure of $80-90$ atmospheres, there exists identity between the vapour and the condensed portion of the body.

LA CosTe describes (Berichte, xviii. 21 22) a modification of V. Meyer's apparatus whereby the densities of easily decomposed compounds may be determined at low temperatures under smal pressures.

\section{GEOGRAPHICAL NOTES}

A CATALOGUE of the printed maps, plans, and charts in the British Museum has been prepared by Prof. Douglas, and will be issued in two large volumes. It represents the contents of the manuscript catalogue in 323 volumes, the catalogue of the maps and plans in the Royal Library in two printed volumes, and the manuscript catalogue of charts in the same library. The original manuscript catalogue was made inder the superintendence of Mr. Major, late Keeper of the Department of Maps. The orthography adopted in the present catalogue is that used in Keith Johnston's "General Dictionary of Geography," with the exception of India, for which Hunter's "Gazetteer" has been taken as a guide. The utility of this catalogue to the geographical student will be found in the comparatively simple alphabetical arrangements for the heading; of countries and places, combined with the names of geographical writers, which last often serve a; short cuts to any particular atlas or map. Thus, under the head of "Ptolemy," the pillar and foundation of ancient geography, there are seventy-four entries referring to the various editions and copies of his "Geographica." Turning to the names of the fathers of modern geography, Ortelins and Mercator, we find under the former twenty-nine entries describing the various copies and editions of his "Theatrum orbis Terrarum." The geographical labours of his contemporary and friend, Mercator, will be best realised by a reference to the 